Acta Theriologica 37 (1 - 2): 193 - 198, 1992.

PL ISSN $0001-7051$

FRAGMENTA THERIOLOGICA

\title{
Spring diet of the American mink Mustela vison in the Mazurian and Brodnica Lakelands, northern Poland
}

\author{
Marcin BRZEZIŃSKI ${ }^{1}$ and Wirgiliusz ŻUROWSKI
}

\begin{abstract}
Brzeziński M. and Zurowski W. 1992. Spring diet of the American mink Mustela vison in the Mazurian and Brodnica Lakelands, northern Poland. Acta theriol. 37: $193-198$.

The analysis of 110 American mink Mustela vison Schreber, 1777 faeces, collected in May and June during 1987 - 90, from beaver lodges in the Mazurian and Brodnica Lakelands (northern Poland), showed great diversity in the food eaten. Mammals dominated in the diet ( $61.8 \%$ of occurrence). Among them, Arvicola terrestris and Microtus sp. (mainly $M$. oeconomus) were most numerous. No beaver kit remains were recorded. Birds, amphibians, fish and crayfish were also important components of the mink diet. Each of these groups were found in about $25 \%$ of scats. The mink was found to be a typical generalistic predator. The diversity of the mink diet, most probably, was made possible by the abundant and diverse food resources in late spring.

Mammal Research Institute, Polish Academy of Sciences, 17-230 Białowieża, Poland (MB); Research Station of the Polish Academy of Sciences, Popielno, 12-222 Wejsuny, Poland (WZ)
\end{abstract}

Key words: Mustela vison, diet, Poland

\section{Introduction}

The wild-living American mink Mustela vison Schreber, 1777 appeared in Poland at the turn of the 1950s and 1960s (Ruprecht et al. 1983). Observed individuals escaped from farms or were immigrants from Belarus and Lithuania (Ruprecht et al. 1983, Schmidt and Kaszuba 1985, Żurowski and Kammler 1987, Wolny 1987). However, stable populations of these predators were probably not established until the early 1980 s. Mink were observed most often in north-eastern Poland (Ruprecht et al. 1983, Schmidt and Kaszuba 1985, Zurowski and Kammler 1987). Romanowski et al. (1984) suggested that in the early 1980 s wild-living mink populations also occurred in central and western Poland.

The appearance of the American mink in northeastern Poland was suggested as a factor for the decline of local populations of muskrats and some waterfow species, mainly mallards and coots (Żebrowski 1987, Wolny 1987, Balerstet et al.

\footnotetext{
${ }^{1}$ Present address: Department of Ecology, University of Warsaw, Krakowskie Przedmiescie 26/28, 00-927 Warsaw, Poland
} 
1990). However, up till now except for a note by Balerstet et al. (1990), no studies on mink diet have been undertaken in Poland.

In Western and Northern Europe the American mink also became a new species of fauna. Contrary to Poland, many studies on food and predation by mink (e.g. Gerell 1967, 1968; Akande 1972, Day and Linn 1972, Niemimaa and Pokki 1990), as well as competition with other predators (Erlinge 1969, 1972; Jenkins and Harper 1980, Chanin 1981, Wise et al. 1981) have already been undertaken.

Zurowski and Kammler (1987) observed the American mink in the Mazurian and Brodnica Lakelands, inhabiting beaver lodges and their vicinities. In spring beaver kits were very small (the average weight of beavers at birth amounted 523 $\mathrm{g}, \mathrm{SD}=109 \mathrm{~g}$, Żurowski 1983). These facts suggested that mink could easily prey on young beavers and consequently limit their number.

During the last few decades, beavers Castor fiber Linnaeus, 1758 were reintroduced into many places in Poland, and now their numbers have rapidly increased (Żurowski and Kasperczyk 1988). Therefore, mutual interactions of increasing American mink and beaver populations should be carefully studied. The aim of this note is to report on the diet of mink co-occurring with beavers in Poland.

\section{Study area}

Mink scats were collected in 19 beaver lodges, distributed in the southern part of the Mazurian Laikeland $\left(53^{\circ} 30^{\prime}-53^{\circ} 50^{\prime} \mathrm{N}, 21^{\circ} 10^{\prime}-22^{\circ} 25^{\prime} \mathrm{E}\right)$ and in the southwestern part of the Brodnica Lakeland $\left(53^{\circ} 0^{\prime}-53^{\circ} 15^{\prime} \mathrm{N}, 19^{\circ} 20^{\prime}-19^{\circ} 40^{\prime} \mathrm{E}\right)$, northern Poland. The Mazurian Lakeland is composed of many small, medium, and large lakes. Most of them are surrounded by forests. Lakes are joined together by small rivers and canals (beavers were introduced mainly in such places). Most of the surveyed beaver lodges existed there. In the Brodnica Lakeland numerous lakes and marshes lie in the agricultural landscape, and are joined together with many irrigation canals. Beavers live here mainly in the marshes. This area is not rich in water, and small marshes and canals dry up seasonally.

\section{Material and methods}

Altogether, 110 mink scats were collected in May and June, from 1987 to 1990. Scats were analysed using the standard method of washing through a $0.5-\mathrm{mm}$ sieve and drying at a temperature of $50^{\circ} \mathrm{C}$ (Lockie 1959). The remains of prey items were identified according to the keys by Pucek (1981), Debrot (1982) and März (1987), and comparative collections of skeletons. The contribution of each kind of prey to the mink diet was presented as a precentage of their occurrence in the whole sample, and as a percentage of biomass consumed. For estimating the biomass of eaten food items correction factors given by Fairley and Ward (1987) for American mink, and Lockie (1961) for pine marten were used (Table 1). The size of eaten fish was estimated according to Wise (1980).

The Levins' food niche breadth index (Levins 1968) $B=1 / \Sigma p^{2}$, where $p$ is the percentage biomass of a particular prey item, was calculated to show the degree of food specialization by mink.

\section{Results}

The composition of the American mink spring diet is shown in Table 2. None of the analysed scats contained any beaver remains. Mammals dominated in the 
Table 1. Correction factors used for estimating the biomass of eaten prey, according to Fairley and Ward 1987 (1) and Lockie 1961 (2).

\begin{tabular}{lcl}
\hline Prey item & Correction factor & \multicolumn{1}{c}{ Source } \\
\hline O. zibethicus & 20 & (1) for a large rat \\
A. terrestris & 15 & (1) for an average rat \\
Microtus sp. & 9 & $(1)$ \\
C. glareolus & 9 & $(1)$ \\
Apodemus sp. & 9 & $(1)$ \\
Insectivora, M. minutus & 5 & (1) for a shrew \\
Aves & 12 & $(1)$ \\
Amphibia, Reptilia & 18 & (1) for amphibians \\
Pisces & 25 & (1) \\
Crustacea, Gastropoda & 7 & (1) for crayfish \\
Insecta, Arachnida & 5 & (2) for insects \\
\hline
\end{tabular}

mink diet. Arvicolidae (mainly Microtus oeconomus but also M. arvalis) and Arvicola terrestris were the most frequently eaten mammals. The contribution of muskrat Ondatra zibethicus to the mink diet was very low, only about $1 \%$ of the biomass.

Amphibians and birds were also important components in the mink diet (Table 2). A reasonable number of eaten birds were nestlings. Fish composed nearly $16 \%$ of the biomass. The fish eaten were very small and their average body length was $11.5 \mathrm{~cm}, \mathrm{SD}=4.4 \mathrm{~cm}$ (sizes ranged from 7.0 to $23.0 \mathrm{~cm}$ ). Eighty-five per cent of fish did not exceed $15 \mathrm{~cm}$.

The mink food niche breadth approached 4.0 (calculated for 6 groups of prey). The obtained value (the possible range of $B$ is 1 to 6 ) was very high and shows that mink have opportunistic feeding habits.

\section{Discussion}

Many previous studies on the feeding habits of the American mink showed that this predator is a generalist, choosing the most readily available prey (Chanin and Linn 1980, Wise et al. 1981). Mink hunt many kinds of prey, including aquatic, semi-aquatic and terrestrial animals (review in Eagle and Whitman 1987). Mammals are usually the most frequently eaten group and among them small Arvicolidae are often the most important (Gerell 1968, Erlinge 1972, Jenkins and Harper 1980). The high predation by mink on Microtus oeconomus and Arvicola. terrestris in northern Poland, is therefore typical for this mustelid. Among other consumed mammals, the relatively low number of insectivores can be explained by their bad taste (Korpimäki and Norrdahl 1989). In turn, the surprisingly small frequency of muskrat remains, which is contradictory to the previous observations 
Table 2. Diet composition of the American mink in the Mazurian and Brodnica Lakelands in spring (May - June) $1987-1990 . N=110$ scats.

\begin{tabular}{|c|c|c|}
\hline Prey item & $\%$ Occurrence & $\%$ Biomass \\
\hline Ondatra zibethicus & 2.7 & 1.1 \\
\hline Arvicola terrestris & 22.7 & 23.1 \\
\hline Microtus oeconomus & 12.7 & \\
\hline Microtus arvalis & 1.8 & \\
\hline Microtus sp. & 15.5 & \\
\hline Microtus - sub-total & 30.0 & 13.0 \\
\hline Clethrionomys glareolus & 1.8 & \\
\hline Apodemus sp. & 1.8 & \\
\hline Micromys minutus & 0.9 & \\
\hline Neomys fodiens & 1.8 & \\
\hline Sorex araneus & 2.7 & \\
\hline Sorex minutus & 1.8 & \\
\hline Sorex sp. or Neomys sp. & 0.9 & \\
\hline Insectivora - sub-total & 7.3 & 1.2 \\
\hline Mammalia & 61.8 & 40.0 \\
\hline Large birds, undet. (probably Anseriformes) & 9.1 & \\
\hline Nestlings & 5.5 & \\
\hline Eggs & 4.5 & \\
\hline Small Passeriformes & 0.9 & \\
\hline Aves, undet. & 7.3 & \\
\hline Aves & 22.7 & 12.5 \\
\hline Lacerta sp. & 0.9 & \\
\hline Reptilia & 0.9 & + \\
\hline Rana temporaria & 1.8 & \\
\hline Rana sp. & 6.3 & \\
\hline Anura, undet. & 20.0 & \\
\hline Amphibia & 26.4 & 19.6 \\
\hline Esox lucius & 3.6 & \\
\hline Perca fluviatilis & 3.6 & \\
\hline Cyprinidae & 7.2 & \\
\hline Pisces undet. & 10.9 & \\
\hline Pisces & 25.5 & 15.7 \\
\hline Crustacea & 27.3 & 11.5 \\
\hline Gastropoda & 0.9 & + \\
\hline Dytiscidae & 11.8 & 0.6 \\
\hline Insecta, undet. & 10.9 & \\
\hline Insecta & 22.7 & 0.7 \\
\hline Mean biomass consumed per scat (g) & & 14.4 \\
\hline Niche breadth index $B$ & & 4.0 \\
\hline
\end{tabular}


on mink predation made by Żurowski and Kammler (1987) and Balerstet et al. (1990), resulted from the low numbers of these rodents in the studied habitats (W. Żurowski, unpubl. data).

Young beavers were not eaten by minks. Beaver kits were probably sufficiently guarded by their parents and mink were not able to enter the beaver lodges without exposing themselves to attacks by adults. Studies on the otter Lutra canadensis diet, undertaken in beaver lodges in Canada, also showed that otters did not prey on young beavers (Tumilson and Karnes 1987). It seems that both otters and mink, despite the fact they often live in and around beaver lodges and burrows (Żurowski and Kammler 1987, Reid et al. 1988), do not feed on these large rodents.

The importance of birds in the mink diet in spring resulted from their increased vulnerability to predation in the breeding season. The contribution of birds to the mink diet usually increases in this period (Gerell 1968, Niemimaa and Pokki 1990).

The large number of small fish eaten by mink, observed also by Gerell (1968), reflects the hunting strategy of this predator. Poole and Dunstone (1976) observed that mink hunt fish from the banks, looking for them from above the water. This hunting strategy enables the mink to capture mainly small fish, inhabiting the shallow waters close to the bank.

The obtained results support previous observations on opportunistic feeding habits of American mink. The high diversity of food taken by mink in the Mazurian and Brodnica Lakelands was probably enhanced by the late spring season, in which the composition of mink diet changed rapidly and became much more diversed than in winter and early spring (cf. Gerell 1968). Also, the large number of studied sites increased the diversity of prey found in mink scats.

\section{References}

Akande M. 1972. The food of feral mink (Mustela vison) in Scotland. J. Zool., Lond. 167: 475 - 479.

Balerstet J., Balerstet T., Wargacki K. and Zurowski W. 1990. Muskrat, Ondatra zibethicus Linnaeus, 1766 and American mink, Mustela vison Schreber, 1777 in the "Drużno Lake" reserve. Prz. zool. 34: 339 - 347. [In Polish with English summary]

Chanin P. R. F. 1981. The diet of the otter and its relations with the feral mink in two areas of Southwest England. Acta theriol. 26: $83-95$.

Chanin P. R. F. and Linn I. J. 1980. The diet of the feral mink (Mustela vison Schreber) in Southwest Britain. J. Zool., Lond. 192: 205 - 223.

Day M. G. and Linn I. J. 1972. Notes on the food of feral mink Mustela vison in England and Wales. J. Zool., Lond. 167: 463- 473.

Debrot S. 1982. Atlas des poils de mammifres d'Europe. Universite de Neuchatel: $1-208$.

Eagle T. C. and Whitman J. S. 1987. Mink. [In: Wild furbearer management and conservation in North America. M. Novak, J. A. Baker, M. E. Obbard and B. Mallo, eds]. The Ontario Trapers Association, Ontario: $615-624$.

Erlinge S. 1969. Food habits of the otter (Lutra lutra) and the mink (Mustela vison) in a trout water in southern Sweden. Oikos 20: $1-7$.

Erlinge S. 1972. Interspecific relations between otter (Lutra lutra) and mink (Mustela vison). Oikos 23: 327-335. 
Fairley J. S., Ward D. P. and Smal C. M. 1987. Correction factors and mink faeces. Ir. Nat. J. 22: $334-336$.

Gerell R. 1967. Food selection in relation to habitat in mink (Mustela vison Schreber) in Sweden. Oikos 118: $233-246$.

Gerell R. 1968. Food habits of the mink Mustela vison Schreb., in Sweden. Viltrevy 5: 119 - 211.

Jenkins D. and Harper R. J. 1980. Ecology of otters in northern Scotland. II. Analyses of otter (Lutra lutra) and mink (Mustela vison) faeces from Deeside, N.E. Scotland in 1977 - 78. J. anim. Ecol. 49: $737-754$.

Korpimäki E. and Norrdahl K. 1989. Avian and mammalian predators of shrews in Europe: regional differences, between-year and seasonal variation, and mortality due to predation. Ann. Zool. Fennici 26: $389-400$.

Levins R. 1968. Evolution in changing environments. Princeton University Press, Princeton, N.Y.: 1 120.

Lockie J. D. 1959. The estimation of the food of foxes. J. Wildl. Manage. 23: $224-227$.

Lockie J. D. 1961. The food of pine marten Martes martes in West Ross-Shire, Scotland. Proc. zool. Soc. Lond. 136: $187-195$.

März R. 1987. Gewoll- und Rupfungskunde. Akademie-Verlag Berlin: 1 - 398.

Niemimaa J. and Pokki J. 1990. Minkin ravinnosta Suomenlahden ulkosaaristossa. Suomen Riista 36: 18 - 30. [In Finish with English summary]

Poole T. B. and Dunstone N. 1976. Underwater predatory behaviour of the American mink (Mustela vison). J. Zool., Lond. 178: $395-412$.

Pucek Z. 1981. Keys to vertebrates of Poland. Mammals. PWN-Polish Scientific Publishers, Warszawa: $1-367$.

Reid D. G., Herrero S. M. and Code T. E. 1988. River otters as agents of water loss from beaver ponds. J. Mammal. 69: $100-107$.

Romanowski J., Kaszuba S. and Koniewski P. 1984. New data on the occurrence of minks (Mammalia, Mustelidae) in Poland. Prz. zool. 28: 221 - 223. [In Polish with English summary]

Ruprecht A. L., Buchalczyk T. and Wójcik J. M. 1983. The occurrence of minks (Mammalia: Mustelidae) in Poland. Prz. zool. 27: 87 - 99. [In Polish with English summary]

Schmidt K. and Kaszuba S. 1985. Rezerwat “Jezioro Drużno” ostoją norki amerykańskiej. Łow. pol. 6: 25.

Tumilson R. and Karnes M. 1987. Seasonal changes in food habits of river otters in southwestern Arcansas beaver swamps. Mammalia 51: $225-231$.

Wise M. H. 1980. The use of fish vertebrae in scats for estimating prey size of otters and mink. J. Zool., Lond. 192: 25-31.

Wise M. H., Linn I. J. and Kennedy C. R. 1981. A comparision of the feeding biology of mink Mustela vison and otter Lutra lutra. J. Zool., Lond. 195: $181-213$.

Wolny W. 1987. Wyderka błotna. Łow. pol. 2: 9.

Żebrowski J. 1987. Norka północno-amerykańska w Puszczy Białowieskiej. Łow. pol. 2: 9.

Zurowski W. 1983. Rozmnażanie się bobrów europejskich w warunkach fermowych. Rocz. Nauk Roln. D 193: $1-71$.

Zurowski W. and Kammler J. 1987. American mink (Mustela vison Schreber, 1977) in beaver's sites. Prz. zool. 31: 513 - 521. [In Polish with English summary]

Zurowski W. and Kasperczyk B. 1988. Effects of reintroduction of European beaver in the lowlands of the Vistula basin. Acta theriol. 33: 325 - 338.

Received 13 March 1992, accepted 30 March 1992. 